\title{
2X-121 DRP
}

National Cancer Institute

\section{Source}

National Cancer Institute. 2X-121 DRP. NCI Thesaurus. Code C159907.

A screening assay that uses messenger RNA gene expression signatures from patient biopsies to identify patients with a high likelihood of responding to PARP/T ankyrase Inhibitor 2X-121 (2X-121). 